\title{
A Research on Problems in the Management of Universities' Official Visit Funds ---A Case Study of Beijing University of Agriculture
}

\author{
Li Shaojing, Huo Chunyan, Zhang Zhiyong \\ International Cooperation and Exchange Department, Beijing University of Agriculture, Beijing 102206 \\ zdflsj@hotmail.com
}

\begin{abstract}
This paper makes an analysis of problems of sources and disbursement of universities' official visit funds and from the perspective of functions of foreign affairs department, the paper brings up strategies dealing with problems in the management of official visit funds and official visit tasks as well as the tentative plan of construction of official visit management team.

Index Terms - Official Visit, Funds, Management Team
\end{abstract}

\section{Problems and Challenges}

With the deep advancement in constructing a clean and honest administration environment in educational system, the effective management of official visit funds has become an important indicator of universities' foreign affairs. In recent years, superior competent department implements "amount limit" management of official visit funds of universities, such as Beijing University of Agriculture, with annual official visit funds amount limited to RMB 550,000. For funds which can be used for official visit, however, in addition to financial appropriation, there are also funds from many kinds of channels, among which, there are not only "longitudinal funds", namely financial appropriation from related ministries and commissions, but also "transverse funds", namely university science and technology revenue-generating funds from society.

Currently, the management of these funds mainly has the following malpractices: (1) visit funds management comes apart with visit tasks management, and due to the existing of many channels of visit funds, foreign affairs department of universities cannot fully grasp them; however, foreign affairs department is responsible for the management of official visit funds of the university, so visit tasks cannot fully match with corresponding visit funds, seriously affecting teachers' official visit activities; (2) university-related departments are not concordant, and official visit is under "centralized" management of foreign affairs department; however, because official visit is involved with visitors' unit, teaching, human affairs, scientific research, finance and other departments, it is a systematic work, needing cooperation of various departments to implement effective management; (3) "longitudinal funds" and "transverse funds" are different in the width of disbursement scope, with diversified requirements, not forming normative management model.

\section{Thinking and Countermeasures}

As far as these problems are concerned, the author thinks it is necessary to discuss management model of official visit funds.

Firstly, clear off university visit funds and funds classification of funds of foreign affairs department. Official visit funds refer to visit funds of whole university, taking Beijing University of Agriculture for example, these funds include (1) visit funds of foreign affairs department, such as annual financial visit funds amount limit; (2) teachers' scientific research projects funds, such as funds used in teachers' project from National Natural Science Foundation of China (NSFC), and funds exclusively used in exchange with foreign countries; (3) special training funds given by superior management department to personnel office, organization department and other university functional departments, such as Beijing Municipal Education Commission's colleges and universities teachers training project; (4) cooperative education projects funds, such as funds in the project international schools and British Harper Adams University to support related teachers' exchange visit; (5) overseas student scholarship project, such as Beijing Municipal Education Commission's government scholarship project and principal overseas student funds of Beijing University of Agriculture, etc. And funds of foreign affairs department only include one of the above items, namely annual financial visit funds amount limit. Official visit funds and funds of foreign affairs department are whole and part in relationship, and funds of foreign affairs department cannot cover foreign affairs activities of whole university.

Secondly, the management of these funds should focus on official visit tasks and establish normative management model. Foreign affairs department carries out total management of official visit tasks of whole university, and implements whole university overall situation "great foreign affairs" management model. Visit funds of university groups is disbursed from funds of foreign affairs department; visit funds of teachers of secondary colleges is disbursed from scientific research funds; visit funds of teachers of cooperative education projects is disbursed from relevant project unit; visit funds of students is subsidized by government overseas student scholarship and principal overseas student scholarship. The advantages of such management are mainly reflected in: (1) being convenient for 
strict check on the quality of visit tasks; (2) being convenient for visit achievements shared by various colleges of whole university; (3) being convenient for the formulation of visiting plan around large target of university education and teachers. Implementation methods can be: annual visiting plan submitted by various colleges, overall plans and coordination made by international office, reported to personnel office and administration office of university, work tasks and time arranged according to visit tasks, corresponding funds matched by finance department, etc.

Thirdly, establish a multi-level, multi-department participated foreign affairs management team. International office takes charge of centralized management, sets up secondary college competent leadership and part-time foreign affairs secretary post, and forms whole staff participation official visit management model from functional departments to various secondary colleges, from managers to teachers.

In short, with the internationalized development of higher education, the increasing times of university teachers' official visit as well as the diversification of visit funds origin, the management of official visit funds disbursement is facing with increasingly prominent problems. Universities should take foreign affairs department as a centralized management unit, formulate normative management model and establish stratified management team together with other departments to lay a solid foundation for the development of foreign affairs work.

\section{References}

[1] Du Xiaolin, Li Shaojing. A Research and Practice on the International Cooperation of Urban Agriculture Higher Education. ERMI 2012, 528532. ISBN 978-1-61275-049-1.

[2] Li Shaojing. Exploration of Main Body Consciousness of Beijing University of Agriculture in the Process of Internationalization, Supplement of Journal of Beijing University of Agriculture, 2007 (22): 59-61.

[3] Zhou Yan, Zhai Yajun, Zheng Xiaoqi. Countermeasures against Scientific Research Funds Management in Chinese Colleges and Universities, Journal of University of Science \& Technology Beijing (Social Science Edition), 2010, (26): 167-170. 